\title{
The Teachers Academy for Mathematics and Science
}

\author{
EXECUTIVE SUMMARY \\ and \\ PROGRAM ACTIVITIES UPDATE
}

DOE/ER/75603--1

DE92 019141

\section{The Need}

In his State of the Union address on Janualy 31, 1990, President Bush set a goal for U.S. students to be number one in the world in mathematics and science achievement by the year 2000. The Teachers Academy for Mathematics and Science in Chicago is an experiment of unprecedented boldness and scale that can provide a means to the President's goal, both for the Chicago area and as a national model.

In a major urban setting and in a wide-reaching format, the Teachers Academy addresses the major and well-documented concems with national math and science education: inadequate teacher preparation in science and mathematics content; the lack of adequate instructional materials, particularly those for hands-on, quantitative mathematics and science activities; the lack of rigor in and coordination of mathematics and science curnicula; limited emphasis on problem-solving and real world applications; and poor general understanding of the critical thinking skills that provide the basis for modern technology.

These problems are particularly severe in large urban areas and in the Chicago Public Schools. If we can solve these problems in Chicago, and we believe we can, they can be solved anywhere. Chicago is a microcosm of the nation, and its public school system is typical of the nation's large, dysfunctional urban school systems. Therefore, the Academy will focus initial intensive staff development efforts on the Chicago Public Schools while developing programs and its ability to serve the entire metropolitan Chicago area.

The Chicago Public School system, the nation's third largest, with 410,000 students, is plagued by high drop-out rates, declining test scores, frustrated teachers, and threatening gang and drug problems. Its students are 60\% African-American, 21\% Hispanic, 13\% Caucasian and 3\% others. All of these groups include diverse subcultures and many recent immigrants. Our schools serve students who speak 84 different languages.

Approximately $67 \%$ of the students' families live on incomes below the poverty line. The high school drop-out rate is $41 \%$ citywide with much higher rates in lower socio-economic and 
minority schools. Of these who graduate. only one fourth can read at the welfth grade level. In 1988-89,70.1\% of elementary school students scored below grade level in math on the nationally standardized Test of Achievement and Proficiency (TAP). A revolution is needed in the classroom to keep students in school, and to educate them so they can productively entris the work-force.

\section{Organization 스 Governance}

The Teachers Academy was founded in 1990 as a project of the Chicago Education Federation, which is govemed by a Council of Presidents composed of the Presidents or Chancellors of 13 leading Chicago-area colleges and universities. In addition to appointing the Teachers Acadeny Board of Directors, the Council of Presidents (through its University/Academy Cooperating Committee) has taken an active role in coordinating the objectives of the Teachers Academy and the various universities, in involving the Academy in the development and operation of pre-service programs, and in developing and coordinating collaborative projects. Meaningful activities have already occurred, including the donation of 18 months of rent-free space to house the Acajemy at the Illinois Institute of 'Technology Research Institute, and the loan of curricular experts from the University of Illinois at Chicago and the University of Chicago to serve as initial Academy faculty and trainers and provide input into design and development of program content. The University of Chicago and the two research laboratories (Argonne and Fermilab), also donated crucially-needed staff and financial support during the Academy's sti -up phase. Further, there are plans in progress for additional loaned faculty, dual appointments, the use of undergraduate volunteers in Academy programs, and the collaborative development of college-credit follow-up programs for Teachers Academy graduates.

The Teachers Academy for Mathematics and Science links a vast array of local resources to the needs of local schools. At the leadership level, local education, business, government, research, and civic leaders worked together on the Board of Directors to formulate founding policies. In addition to notable corporate and foundation financial and in-kind support, local businesses and research groups provided pro bono services such as legal counsel, personnel and facility" management. Loaned executives and support staff from Centel, AT\&T and Leadership for Quality Education filled key' start-up roles and Friends of Fermi (a nonprofit affiliate of the Fermi National Accelerater Laboratory) served as fiscal agent during the Teachers Academy's formative stages. The Academy's founding Acting Director, Dr. H. Gordon Berry, served for seven months on loan from Argonne National Laboratory.

An organizational chart is provided in Appendix A. 


\section{Program Activities}

The Academy has an extensive and detailed plan of operation, both short-tem and long-term, that includes three major efforts: the Intensive Staff Development Program for Chicago Public School teachers, Outreach (Special. Focus Work shops and Programs) for all metropolitan Chicago and Illinois teachers, and a comprehensive Resource Center.

\section{A. The Academy Intensive Staff Development Program}

The Chicago Public Schools are the initial target of the Academy Intensive Programs. To qualify for participation in the Academy Intensive Staff Development Program, the principal and at least $60 \%$ of the teachers and $70 \%$ of the Local School Council must support their school's participation. The Intensive Staff Development Program includes three segments: the School /Community Relations segment; the Intensive Program; and, the Follow-up Segment.

\section{School/Communitu Relations and School Recruiment}

Before the Intensive Staff Development Program begins, an Academy School Community Relations liaison works with the principal, staff, parents, PPAC, and Local School Council to assess the needs of the school and is teachers in the areas of mathematics and science teaching and learning. Particular care is taken to match the Academy programs with the needs identified by Local School Improvement Plan. Orientation sessions, as well as continuing follow-up sessions are provided for principals and Local School Councils on whole school change.

The Teachers Academy works with the whole school and its school leadership (principals, Local School Council memi i:r and the PPAC - a teacher advisory group) to develop a strong and necessary support base so the oppontunity for implementation is stronger. The intent is for the Academy to help the school leadership develop their role to provide curriculum leadership for the school.

In laie August, 1991, the Teachers $f$ cademy sponsored two- and three-day plannins workshops to help the teachers, principals, parents, and students of pilot-phase schools develop detailed plans for integrating mathematics and science curricula at their respective schools. These plans were predicated on new levels of competencs and science/mathematics literacy among faculty. Many planning program participants commented that without Intensive Staff Development Training, they would not have been prepired in either subject mastery or pedagogy to develop and implement such a plan. After the planning workshops, the plans 
were taken back to each school and included in the Local School Council's School Improvement Plan.

A flow chart can be used (see Appendix B) to show the pathway that a school follows as it participates in the School Change progam of the Teachers Academy. This flow diagram actually shows the proposed model to be used in 1992. The current (Fall 1991) model is similar in design but has the School Leadership Tean development as a followup activity in the semester following the Intensive Staff Development Program. In 1992 the participating school will define its goals and establish a School Leadership team before its teachers participate in the semester long intensive program experience. This will enable the Teachers Academy to be more responsive to the school's needs with its programming and thus ensure a greater chance of the school implementing program improvements for the long term.

\section{Intensive Staff Development Program}

Participating teachers rotate between scheduled Academy classes and "laboratory time" with their students. This allows a gradual introduction of sew ideas / methods and provides forums for discussions of implementation problems and successes. Since the program period began February 18, 1991, 442 teachers (262 Teachers in Fall 1991) from 21 elementary schools throughout Chicago have participated in Intensive Staff Development programs. An additional 290 teachers are enrolled in the Spring 1992 semester. This Intensive Program is designed to:

1. help teachers leam how to be curriculum innovators and contributors to their School Improvement Plans;

2. instruct teachers in one or more models of cumiculum instruction in mathematics and science; and

3. introduce teachers to other curriculum models, technological applications and methods for integrating new skills into other course areas.

In the current Intensive Staff Development Program, (see the Intensive Program Flow Chart in Appendix C) teachers come to the Teachers Academy for two days every two week period for a total of 16 weeks. To ease the process of the participating teacher leaving the classroom, an Academy Cooperating Teacher (also called an "Academy Replacement Teacher") replaces the participating teacher so that the participating teacher can attend classes at the Academy. In addition, the Academy Cooperating Teacher co-teaches a third day with the participating teacher to help with the transition and the introduction of new teaching ideas into the classroom. The Academy feels that it is important for teachers to have this chance to try out the teaching 
activites or strategies in their classroom after each Academy session.

The Academy provides teachers with opportunities in capacity building where the teacher can learn: about recent advances in learning research, curriculum and material evaluation, background-content and pedagogy, dealing with multicultural diversity, and student assessment. Time is also spent in a concentated experience in content and pedagr gy of a particular curricular program and exposure to other programs. The intent is to help the teacher become confident and thus able to take control of curriculum planning and become instructional leaders in their own classrooms.

During the 1991 pilot experience with the TAMS Intensive Staff Development programs, teachers were introduced to either Math Tools for Teachers (developed by the University of Chicago School Math Project) or Teaching Integrated Mathematics and Science (TIMS; cleveloped by the University of Illinois). Our initial experiences with this program verified our premise that most elementary school teachers have an inadequate mastery of either science or mathematics and have inadequate capabilities to relate either discipline to the environment of students.

\section{Follow-up}

Intensive Program Follow-up takes place during the semester the teachers return to their classrooms. Follow-up is critically important in Chicago's inner city schools because the demands on these schools and the needs of the teachers and students are so great. Without continuing support, the heavy daily demands on teachers can overwhelm new initiatives. In a study reported by Joyce and Showers [Reference: Joyce, B. and Showers, B (1982) The Coaching of Teaching. Educational Leadership, 40(2), 4-10] improved implementation levels of $80-90$ percent were documented when sustained follow-up is added to training. Without follow-up understanding may increase, but only 5-10 percent of training is converted into classroom practice. Sustained follow-up is critical to the Academy's plan.

Academy staff help teachers apply the new techniques they have learned, and help the entire school community restructure the math and science teaching and school learning environment. During the Followup semester an Academy Implementation Specialist is assigned to each participating school. They help teachers implement the new curricula in the classroom; organize equipment and resources; assist teachers with planning; work with the community and the Local School Council to develop a long-term plan for math and science teaching; assist in the further development of school leaders; and work with the school leadership team to 
implement the long-term plan. The School/Community Relations Liaison links the schools with citywide resources - educators, academics, scientists and mathematicians working in industry, and the multitude of other local resources.

\section{B. Outreach Programs}

An important strategy to increase participation in the Academy by educators is the use of Special Focus Workshops and Programs. Previous workshops have focussed on specialized topics in math. science, and student learning styles; mini-courses designed to increase teacher math and/or science literacy, introductions to nationally-recognized programs such as Family Math, Project AIMS, Fast Plants, CSMP, CEPUP, GEMS, FOSS, SCIIS, and others.

Many local institutions and their resources have been our collaborators for Special Focus Workshops and Programs. The Teachers Academy presented jointly-sponsored workshops and seminars with the Museum of Science and Industry, the Adler Planetarium, Fermi National Accelerator Laboratory, the Lincoln Park Zoo, the Field Museum of Natural History, the Golden Apple Foundation, the Chicago Academy of Sciences, Encyclopedia Britannica, the Chicago Board of Education, and others. During the first year (1991) of Academy operations, 3392 teachers benefitted from these programs. Input from community organizations and the Chicago Public Schools was incorporated in program planning, staff and participant training, and program evaluation, to assure that Teachers Academy programs meet community needs. During the pilot year just ended, the necessity for programs to foster linkages between schools, community organizations (including civic groups, businesses, higher education institutions, research organizations, etc.) became increasingly evident. As a result, program plans, such as the use of School/Cornmunity Relations Liaisons and Implementation Specialists, have been expanded.

Many of these programs are conducted jointly with area science institutions such as museums, zoos, research laboratories, corporations, etc. As an example of the breadth of workshop program instruction, a roster of Summer 1991 Special Programs, which included hands-on, activity-based programs in physical and earth sciences, scientific reasoning, technology, astronomy, botany, zoology, and aerodynamics are attached (see Appendix D).

\section{Teacher Resource Center}

The TAMS Resource Center will exist to encourage all elementary, middle and high school teachers in the greater Chicago area to continue their professional growth by bringing them into contact with effective math and science reaching curricula, techniques, demonstrations, technology specialists, and peers in a collegial atmosphere. Our guiding principles in devising the operating 
plan for the Resource Center are to provide materials and services which foster scientific thinking and methods of inquiry; make math and science relevant to urban learmers; and engage the learners' multiple intelligences.

The facility will provide space for laboratory activities, informal gatherings, and for accessing new materials and ideas. Teachers, mentors, researchers, volunteers, and parents are the groups for which the facility is designed. Activities at the Resource Center will include teachers preparing hands-on science activities; peer-teaching and cooperative leaming; seminars, forums, conferences and special-focus classes; developing and reviewing curricula; exploring the use of computers and multimedia technology in math and science instruction; and mentoring and teacher-to-teacher networking. The resource center will operate on an extended daily schedule.

\section{Future Training Goals}

In the 1991-92 school year, we plan to expand the Intensive Staff Development program to approximately 1,400 teachers. In subsequent years, the Intensive program will grow to an annual enrollment of over 2,000 teachers per year. Thus, in approximately eight years, the majority of Chicago Public School teachers will have enhanced abilities to deliver hands-on math and science training and improved professionalism. A corps of leaders, drawn from the teaching staff, administration, School Council, and community will exist for each school. These existence of these leadership groups will insure that dynamic, interactive modes of instruction are used, and work to link their school to the larger educational cornmunity and Chicago's public institutions.

The Special Focus Programs will reach more than 5,000 teachers in 1992, further nurturing the professionalisin and networks of educators, as well as providing improved knowledge of specific content areas all for all Chicago area teachers, drawn from the public and private schools. These programs are crucial to our efforts to extend the impact of the Teachers Academy beyond the immediate need to serve the public schools, and to foster a continuing commitment on the part of educators to professional growth.

The Teacher Resou ca Center will open in 1992 with limited collections, and will grow over the next $1-2$ years into a fully-functional facility equipped to accommodate many thousands of visitors.

The improvements in public education which the Teachers Academy is able to catalyze depend directly upon the number of teachers and community leaders we are able to assist. This, in turn, 
depends upon the level of funding and costeffectiveness of Teacher Academy Programs. The more quickly the Academy reaches fully operational status, the more quickly we will achieve lasting changes in public education in Chicago. Each delay, on the other hand, translates into more students turning away from math and science, and being less capable of functioning effectively in our increasingly complex technologically-based society.

\section{Evaluation Programs}

A full-time evaluation expert will be retained to constuct the evaluation instruments based on the Academy's program goals and objectives. Two components are: a) a program evaluation of the Follow-up Segment and b) an overall formative report on the effectiveness of the total Academy program in meeting its mission and goals.

Since the Academy's programs focus on the teacher, all participating teachers in the project will be asked to complete evaluation forms. Results will be used to provide interim evaluation reports which will coincide with project milestones. The evaluator will then write a final detailed report based on the resuits of the responses to the evaluation instruments. This report will include a description of the program, the goals of the program, an evaluation summary and recommendations (strengths and weaknesses) needed for continuation of the project.

Project evaluation will be two-fold and will include:

1. Formative evaluation: a systematic gathering of data on the program is being conducted by Academy personnel. Data collection techniques so far include survey questionnaires and interviews with teachers, principals, local school council members and classroom observations. Analysis of the data is determining changes to be made to reduce discrepancies for the duration. We will use participating teacher's' responses to provide information as they participate in the follow-up activities. We expect the evaluator to determine the need for additional data collection, such as criterion-referenced test results and attitude surveys.

2. Summative evaluation will be conducted on only the Follow-up Segment of the project. Cumulative data will serve as the basis for maintaining or restructuring the Academy's Follow-up activities. Survey tools will be used to solicit responses on the strengths and weaknesses of the outcomes for follow-up activities conducted in their schools. It will be important that this survey is carried out in a timely and effective manner, that the program is determined to be consistent and that this information is delivered to the appropriate audience for review. 
Formative evaluation reports will be used to improve both the follow-up program and the overall Academy program. These reports have already provided early information of program effectiveness and needed changes that are indicated. We expect these reports to continue to be helpful. The summative evaluation reports will provide information and judgments about the Academy's overall programs and will help other large urban school districts evaluate the program for use in their own systems.

To date, evaluation of the pilot program has been conducted through extensive surveying and interviewing of the participating teachers and principals. Information from these interviews is being used to refine the program, develop training programs for the trainers, and develop followup and outreach to the school and community.

Mid-course surveys of program participants provided convincing evidence that Teachers Academy Intensive Staff Development programs were beginning to raise the level of teachers' subject mastery -- and were further motivating teachers by showing them how to continually upgrade their understanding of mathematics and science concepts in the future, after Academy training is completed.

The Academy Intensive Staff Development Program was designed to provide significant support to the teacher as new curricular models and related scientific concepts are incorporated into the teachers' lesson plans. Given the newness of this program we do not, as yet, have programs in place to measure teachers scientific literacy before and after training. However, feedback to the Academy from the Academy's Replacement Teachers, School/Community Relations Liaisons and Implementation Specialists, from principals, local school council members, from parents and students, and from participating teachers themselves provide convincing evidence that teachers' subject mastery is improving as a direct result of Teachers Academy efforts. (In 1992, after science-specific core programs such as CEPUP [Chemical Education for Public Understanding], CHEM [Chemicals, Health, Environment and Me], the Algebra Project and perhaps some NDN [National Diffusion Network] approved programs are introduced, these factors will be quantified more easily.) Our feedback indicates that teachers are not only improving their understanding of basic concepts --. they are also developing a new level of comfort and competence in their ahility to explain and demonstrate these concepts to students in ways the student can understand. For example, one teacher related that she was now able to teach a concept of electricity by showing how a flashlight works. We have obtained a wealth of anecdotal evidence about teachers' excitement over newly-acquired understanding of their subjects. 
The increase in science literacy for the Teachers Academy's 3392 workshop and seminar participants in 1991 is more readily documented. The results of the AHA! Workshop conducted by the Friends of Fermilab was especially well documented. These one-day-to two-week-long subject-specific programs are designed and presented to increase educator's understanding of scientific concepts to introduce them to new and unfamiliar technologies. These programs help teachers want to learn -- to help thern to overcome mathematics and science anxiety.

\section{DISCLAIMER}

This report was prepared as an account of work sponsored by an agency of the United States Government. Neither the United States Government nor any agency thereof, nor any of their employees, makes any warranty, express or implied, or assumes any legal liability or responsibility for the accuracy, completeness, or usefulness of any information, apparatus, product, or bility for the accuracy, completeness, or usefulness of any information, apparatus, product
process disclosed, or represents that its use would not infringe privately owned rights. Reforence herein to any specific commercial product, process, or service by trade name, trademark, manufacturer, or otherwise does not necessarily constitute or imply its endorsement, recommendation, or favoring by the United States Government or any agency thereof. The views and opinions of authors expressed herein do not necessarily state or reflect those of the United States Government or any agency thereof. 

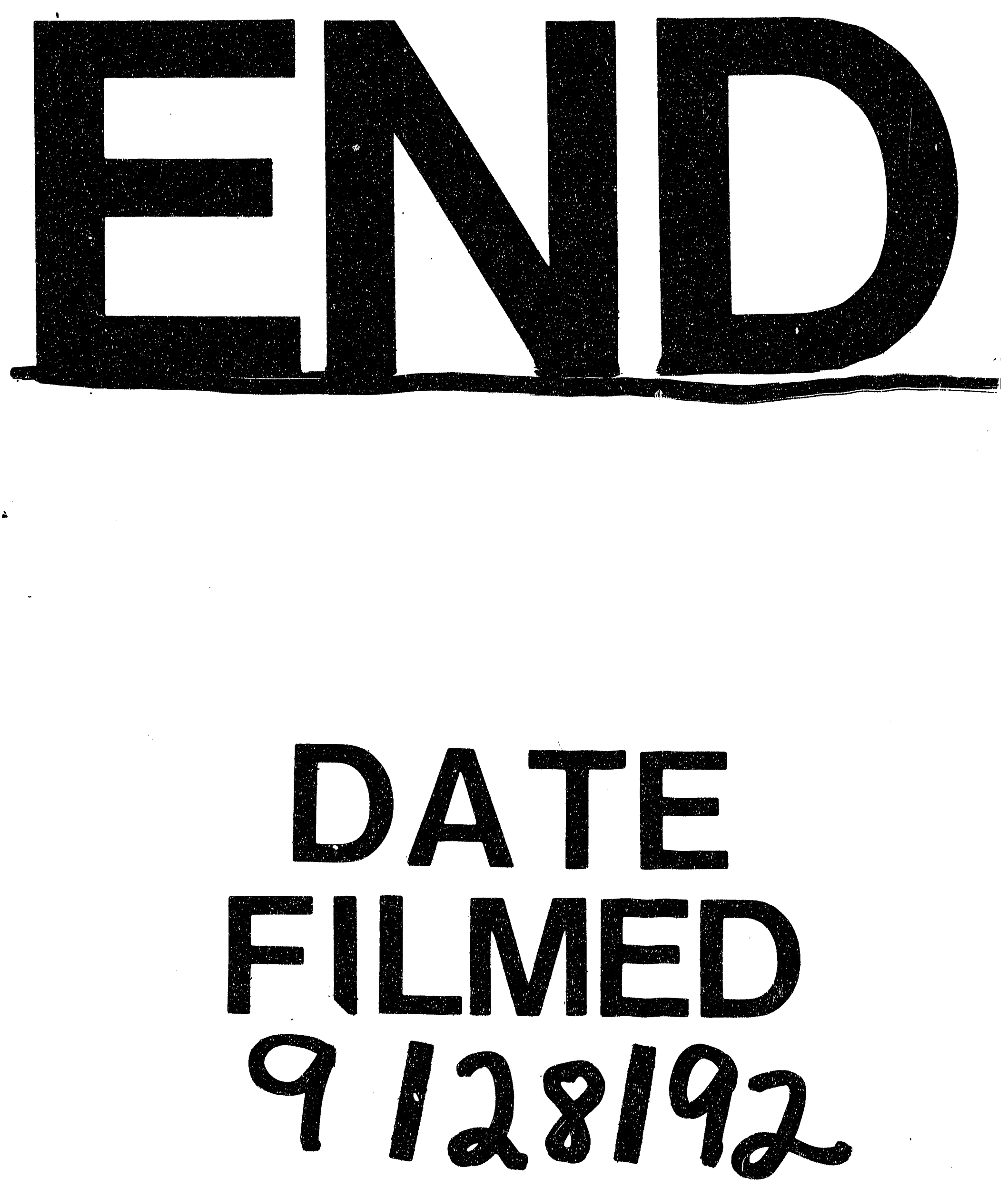
